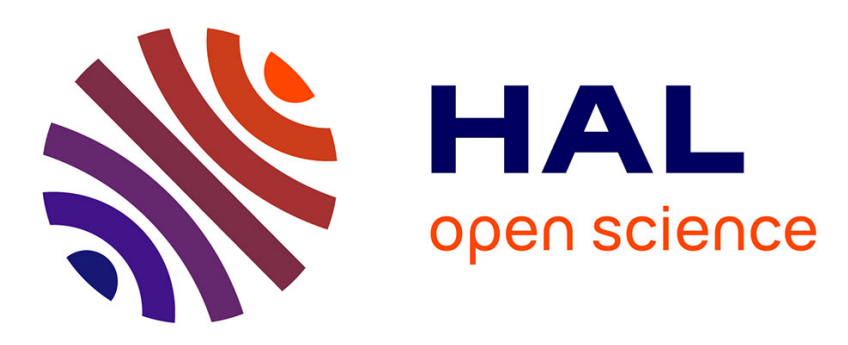

\title{
Eco-friendly redox mediator gelatin-electrolyte for simplified TiO2 -viologen based electrochromic devices
}

Abdelaadim Danine, Laura Maria Manceriu, Alexandre Fargues, Aline Rougier

\section{- To cite this version:}

Abdelaadim Danine, Laura Maria Manceriu, Alexandre Fargues, Aline Rougier. Eco-friendly redox mediator gelatin-electrolyte for simplified $\mathrm{TiO} 2$-viologen based electrochromic devices. Electrochimica Acta, 2017, 258, pp.200-207. 10.1016/j.electacta.2017.10.096 . hal-01646260

\author{
HAL Id: hal-01646260 \\ https://hal.science/hal-01646260
}

Submitted on 23 Nov 2017

HAL is a multi-disciplinary open access archive for the deposit and dissemination of scientific research documents, whether they are published or not. The documents may come from teaching and research institutions in France or abroad, or from public or private research centers.
L'archive ouverte pluridisciplinaire HAL, est destinée au dépôt et à la diffusion de documents scientifiques de niveau recherche, publiés ou non, émanant des établissements d'enseignement et de recherche français ou étrangers, des laboratoires publics ou privés. 


\title{
Eco-friendly redox mediator gelatin-electrolyte for simplified $\mathrm{TiO}_{2}$-viologen
}

\section{based electrochromic devices}

\author{
A. Danine $e^{1,2}$, L. Manceriu ${ }^{1,2}$, A. Fargues ${ }^{1,2}$ and A. Rougier ${ }^{1,2 *}$
}

${ }^{1}$ CNRS, ICMCB, UPR 9048, F33600 Pessac, France

${ }^{2}$ Univ. Bordeaux, ICMCB, UPR 9048, F-33600 Pessac, France

* Corresponding Author: aline.rougier@icmcb.cnrs.fr

Keywords: $\mathrm{TiO}_{2}$, viologen, $\mathrm{I}^{-} / \mathrm{I}_{3}^{-}$redox, edible gelatin, electrochromic device

\begin{abstract}
In the present study, a novel gel electrolyte composition combining lithium iodide LiI in 1-butyl-3-methylimidazolium iodide (BMII) ionic liquid, iodide/triiodide $\left(\mathrm{I}^{-} / \mathrm{I}_{3}^{-}\right)$redox mediator and biodegradable gelatin is proposed for electrochromic devices (ECDs). More precisely, ECDs are assembled using viologen anchored - nanostructured $\mathrm{TiO}_{2}$ (deposited on FTO glass substrate by doctor blading at low temperature) as electrochromic material, FTO as counterelectrode and the gel electrolyte as redox mediator in between. Fast switching times and high cycling stability, up to 20000 cycles, are recorded. The optical reflectance modulation at 550 $\mathrm{nm}$ between white and blue color reaches a contrast value $\Delta \mathrm{R}$ of about $19 \%$ in less than 4 seconds after 100 cycles.

\section{Introduction}

In recent years, the number of articles and patents on electrochromic materials and devices, ECDs, known for the modulation of their optical properties under an applied voltage, have significantly increased in the literature [1-9]. Indeed, ECDs are widely investigated in different commercial applications [10-13] such as displays, rearview mirrors and smart windows for buildings $[14,15]$. Among all materials, the most common electrochromic material remains $\mathrm{WO}_{3}$ [16-18]. As a matter of fact, close to fifteen years ago Granqvist et al. [19] incorporated an $\mathrm{EC}$ foil containing $\mathrm{WO}_{3}$ as the cathodic $\mathrm{EC}$ material and NiO-based as ion storage thin films in helmet visors with variable transmittance from dark state in sunlight to clear state in the dark [20]. However, as a general trend, the electrochromic performance of ECDs based on
\end{abstract}


oxides suffer from a non-negligible operating voltage and a switching time considered as too slow for various applications. Nowadays, the development of ECDs technology is largely focused on $\pi$-conjugated polymers [21-25] such as polyaniline and poly(3,4ethylendioxythiophene) PEDOT [26-31] or chromophore molecules such us bipyridilium derivatives and viologen [32-34]. Hence, high coloration efficiency and fast optical switching time at low operating potentials, including reasonable cost of preparation, are the reasons for which they are classified among the most promising electrochromic materials in the future. The viologens have gained much attention due to their reversible, fast and dramatical optical change between the dication state $\left(\mathrm{V}^{2+}\right.$, bleached) to the radical cation state $\left(\mathrm{V}^{+\bullet}\right.$, colored). However, those materials suffer from agglomeration during operation due to the poor solubility of $\mathrm{V}^{+\bullet}$, resulting in irreversible bleaching [35].

In order to reach high optical contrast in EC displays and avoid agglomeration, Grätzel et al. [36] developed viologen anchored on $\mathrm{TiO}_{2}$ nanoparticles via a phosphoric acid group. This innovative EC material has been rapidly exploited by several research groups such as NTERA [37] in all-printable and flexible EC displays for segmented alpha-numeric and graphical data applications [38]. $\left(\mathrm{TiO}_{2}\right)$ viologen is mostly used in combination with Prussian blue (PB) [[3942] as counter electrode but also with other viologens [43], triphenylamine/triarylamine [43, 44] derivatives or transparent conductors [45, 47] in a traditional five layers structure (transparent conductor/EC1/ion conductor/EC2/transparent conductor), reaching high contrast values, nevertheless associated sometimes to high operating voltages $(2-3 \mathrm{~V}$ [39, 41, 43, 45, 46]).

The idea of using EC technology for applications like anti-counterfeit packaging $[47,48]$ or light control for increased comfort in transport [49] industry, has driven the request for low energy, even user-powered, lightweight and simplified devices. Different strategies have been exploited in viologen devices, like the use of a liquid electrolyte for a faster ionic diffusion and improved electrolyte penetration into the EC layer [44, 45] or the use of viologen itself in a liquid state (device simplification to 4 layers) [50], implying supplementary constraints for assembly and sealing, with negative effects on the device mechanical and cycling stability. From this point of view, the device stability has been shown to be improved by using gel or membrane electrolytes instead of liquid ones [39, 40,42] or by crosslinking viologen with polymer molecules to form a gel or membrane composite (device simplification to 4 layers) $[35,46]$. Focusing on the electrolyte layer, ionic liquids have the advantage to form an electrolytic membrane in the presence of various acrylic polymers [51, 52] or even better solid or condensed electrolyte layer [53] while still keeping their high ionic conductivity $\left(10^{-5} \mathrm{~S} / \mathrm{cm}\right)$ 
at room temperature [54]. In the meantime, biopolymers such as gelatin and Agar-Agar because of their biodegrability, low production cost, good physical and chemical properties, and higher ionic mobility compared to membranes have received significant attention. These kind of materials are widely utilized in the food industries, cosmetic and medical products but can also be used to prepare gel and electrolyte membranes suitable for ECDs [55-57].

Furthermore, in order to achieve a fast switching and device simplification, redox couples like $\mathrm{I}^{-} / \mathrm{I}_{3}^{-}[58-60]$ and tetramethylthioureea [62] were used in $\mathrm{WO}_{3}$ based ECDs as mediator and counter electrode, incorporated in the electrolyte. Likewise, the benefits of using ferrocene $\left(\mathrm{Fc}^{+} / \mathrm{Fc}\right)$ as redox mediator in viologen based ECDs, has also been reported [35, 63], allowing device simplification to 3 [63] and 4 [35] layers.

These studies have driven our work to investigate the possibility of using edible gelatin in mixture with $\mathrm{I}^{-} / \mathrm{I}_{3}^{-}$redox ionic liquid at room temperature (RT), as counter electrode and electrolyte in $\mathrm{TiO}_{2}$-viologen based ECDs. Long-life device is shown (over 20,000 cycles), proving that this electrolyte is a successful candidate for preparing ECDs on heat sensible substrates like plastic or paper.

\section{Experimental methods}

\section{1. Samples preparation}

$\mathrm{TiO}_{2}$-viologen was purchased from NTERA as viscous pale green-white ink $\left(\mathrm{d} \sim 1.36 \mathrm{~g} . \mathrm{cm}^{-}\right.$ ${ }^{3}, \eta \sim 43.5$ Pa.s) which was diluted with ethanol (20\% in vol.) to achieve suitable viscosity ( $\eta$ < 30 Pa.s) for doctor blade coating. Subsequently, a few drops of the as-obtained solution were deposited on ultrasonically cleaned (Fluorine Doped Tin Oxide) FTO-coated glass substrates (Solems ${ }^{\circledR} 10 \Omega / \square$ ) and spread over with a glass rod by using adhesive tape on the edges of substrate which allows to reach a film thickness of about $1.5 \mu \mathrm{m}$. The films were dried in air at $130{ }^{\circ} \mathrm{C}$ for 2 hours, to burn out the residual organic components.

The gel electrolyte was prepared by dipping eatable gelatin in demineralized water (cosolvent) for $10 \mathrm{~min}$ and then adding it, after water soaking, in $0.3 \mathrm{n}$ eq. of lithium iodide (LiI) in 1-Butyl-3-methylimidazolium iodide (BMII) (Solvionic, purity > 99.99\% ) [64] under stirring at $80{ }^{\circ} \mathrm{C}$ for $15 \mathrm{~min}$. The corresponding weight ratio LiI : BMII was optimized as 0.15 : 0.85 . The gel electrolyte was stored in a close beaker for many months in order to ensure its long term stability before devices assembly. 


\section{2. Characterization}

The optical transmittance was recorded in the visible range using a spectrophotometer UviLine 9400. The ionic conductivity was deduced from electrochemical impedance spectroscopy (EIS) at room temperature. A gel electrolyte was studied in sandwiched configuration between two stainless steel blocking electrodes. Both alumina ceramic rings of $1.5 \mathrm{~mm}$ thickness and double adhesive tape were used as separator and to stick the two steel plates on the separator, respectively. All impedance measurements were carried out on a VSPBiologic (Biologic Science Instruments) multichannel potentiostat recorded from $1 \mathrm{MHz}$ to 1 $\mathrm{Hz}$ as frequency range with $20 \mathrm{mV}$ a.c. signal.

\section{3. Electrochromic measurements and device}

For single layers, cyclic voltammetry (CV) and chronoamperometry (CA) measurements were performed at room temperature using a Voltalab PG201 potentiostat in three electrodes cell configuration using platinum foil as counter electrode and $\mathrm{Hg} / \mathrm{HgO}$ as reference electrode (E vs SHE/V $=0.098$ at $25{ }^{\circ} \mathrm{C}$ ) and 0.2 eq. lithium Iodide in 1-Butyl-3-methylimidazolium iodide (purity \# 98\%) (purchased from solvionic $®$ ) as liquid electrolyte. CVs for single layers and devices were recorded at a $10 \mathrm{mV} . \mathrm{s}^{-1}$ scan rate.

The biodegradable gelatin was used as plasticizer in order to build the full ECDs. ECDs were assembled by dropping the gel redox electrolyte on $\mathrm{TiO}_{2}$-viologen film. Using its sticky character, the electrolyte layer was pressed, at room temperature, in between $\mathrm{TiO}_{2}$-viologen and bare FTO-glass substrate with an optimized thickness estimated in between 5 to $10 \mu \mathrm{m}$. For the cathodic electrochromic material, the viologen molecules were modified to contain a phosphate anchor group which allowed fixing them on the surface of the nanostructured $\mathrm{TiO}_{2}$. ECDs can be simply described as a laminated two-layer structure based on $\mathrm{TiO}_{2}$-viologen and redoxgelatin electrolyte.

In-situ reflectance was measured on a Varian Cary 5000 spectrophotometer equipped with a $\phi=10 \mathrm{~cm}$ integrating sphere at a wavelength of $550 \mathrm{~nm}$. The optical contrast was also determined in CIE* $\mathrm{L}^{*} \mathrm{a} * \mathrm{~b} *$ (defined by the CIE, International Commission on Illumination) colorimetric space by Konica Minolta CM-700D spectrophotometer. The contrast $\Delta \mathrm{E}^{*}$ CIE* $\mathrm{L}^{*} \mathrm{a} * \mathrm{~b}^{*}$ was calculated using formula (1) that relates the reduced-blue state $\left(L_{1}^{*}, a_{1}^{*}, b_{1}^{*}\right)$ and oxidized-white state $\left(L_{2}^{*}, a_{2}^{*}, b_{2}^{*}\right)$ :

$$
\Delta \mathrm{E}^{*}=\sqrt{\left(L_{2}^{*}-L_{1}^{*}\right)^{2}+\left(a_{2}^{*}-a_{1}^{*}\right)^{2}+\left(b_{2}^{*}-b_{1}^{*}\right)^{2}}
$$




\section{Results and discussion}

\section{1. LiI/BMII-gelatin electrolyte}

The electrolyte has a transparent-colorless appearance with a transmittance value of about $80 \%$ in the visible range (The transmittance spectra of the electrolyte pressed between to microscope glass slides is shown in Fig. S1 in supplementary information). Basically, the most important electrolyte property is its ionic conductivity that can be evaluated using electrochemical impedance spectroscopy (EIS). Figure 1 shows the Nyquist curve of LiI/BMII15 wt. \% gelatin. The absence of a depressed semicircle, at high frequency, suggests a diffusion process more than a capacitive one [63]. In inset of Fig. 1 the inductance contribution of the wires is visible. The electrolyte resistance $(\mathrm{R})$ resulting from the intercept of the straight line with the real axis exhibits a low value $(\sim 15 \Omega)$ as expected for high ionic conductivity value. The latter was determined for three samples using the formula $\sigma=d / R * S$ where $d$ is the thickness of the electrolyte layer and $\mathrm{S}$ is the contact area between the electrolyte and the stainless steel plate, as shown in Table 1. Thus, an average high ionic conductivity value of 3.6

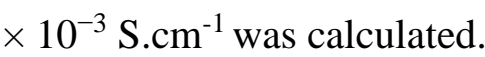

\section{2. Electrochromic results}

Figure 2 shows the first ten cyclic voltammogramms of the $\mathrm{TiO}_{2}$-viologen single electrode measured in a three electrode configuration $\left(\mathrm{TiO}_{2}\right.$-viologen/0.3 eq. LiI-BMII/Pt vs $\mathrm{Hg} / \mathrm{HgO}$ ) at a scan rate of $10 \mathrm{mV} / \mathrm{s}$ by starting on reduction. $\mathrm{TiO}_{2}$-viologen films exhibit a reversible electrochemical response associated with a faradic behavior involving both reduction and oxidation waves, located at $-0.40 \mathrm{~V}$ and $-0.26 \mathrm{~V}$, respectively. Simultaneously, a coloration change occurs from whitish to blue associated with a mechanism described by the injection/extraction of $\mathrm{TiO}_{2}$ conduction band electrons to the viologen LUMO (Lowest Unoccupied Molecular Orbital) band in presence of $\mathrm{Li}^{+}[66]$ as illustrated in the inset of Fig. 2 . This implies that the $\mathrm{TiO}_{2}$-viologen electrode behaves as a conductor rather than as a semiconductor. The position of the conduction band edge of $\mathrm{TiO}_{2}$ is mainly governed by the solvent-electrolyte system [67]. The electrochemical capacity Q, governed by lithium ion insertion/deinsertion, is about $1.8 \mathrm{mC} . \mathrm{cm}^{-2}$ (recorded in oxidation).

Figure 3a shows the second cycle of in-situ reflectance/cyclic voltammetry measurements of the "Glass/FTO/LiI-BMII 15 wt. \% gelatin/FTO/Glass" device cycled at $10 \mathrm{mV} / \mathrm{s}$ in the $1.5 \mathrm{~V}$ to $0 \mathrm{~V}$ potential window. Despite the flat shape of the $\mathrm{CV}$, the reduction peak at $-1.35 \mathrm{~V}$ 
can be clearly associated with the optical change $(\mathrm{R}=37 \%)$ at $-1.15 \mathrm{~V}$ vs. FTO corresponding to the beginning of the coloration process till a stable reflectance value $(\mathrm{R}=18 \%)$ is reached at around $-1.5 \mathrm{~V}$. Thus, a reflectance modulation of $\Delta \mathrm{R} \approx 19 \%$ is recorded whereas the narrow width of the optical cycle indicates a fast coloration process. Indeed, the EC display exhibits color change from blue at $-1.5 \mathrm{~V}$ to milky white at $0 \mathrm{~V}$ resulting from $1 \mathrm{mC} . \mathrm{cm}^{-2}$ as electrochemical capacity (inset of Fig. 3).

Figure $3 \mathrm{~b}$ shows the first ten cycles of the corresponding in-situ reflectance/CA measurements performed in between $-1.5 \mathrm{~V} / 20 \mathrm{~s}$ and $0 \mathrm{~V} / 20 \mathrm{~s}$. Both responses show a good reversible cycling behavior associated with very fast switching times $(<4 \mathrm{~s})$ at $90 \%$ of optical amplitude for $4 \mathrm{~cm}^{2}$ display sized. Besides a similar reflectance modulation, $\Delta \mathrm{R} \approx 19 \%$ proportional to a high $\Delta \mathrm{E}^{*} \mathrm{CIE} * \mathrm{~L}^{*} \mathrm{a} * \mathrm{~b} *$ contrast of around 59 , calculated from the reflectance data is recorded.

Figure 4 shows the architecture with the illustration of the charge transfer taking place inside the EC device. From the in situ reflectance measurement (Fig.3), the device starts to color when $-1.15 \mathrm{~V}$ are applied with report to FTO $(-1.05 \mathrm{~V}$ with report to NHE, since FTO is at 0.1 vs. NHE [68]). Boschloo et al. [67] claimed that the $\mathrm{I}_{2}{ }^{-\cdot}$ radicals are not stable and disproportionate to give $\mathrm{I}_{3}{ }^{-}$and $\mathrm{I}^{-}$(eq. 2) leading to a potential drop. The standard potential of the iodide/triiodide, $\mathrm{I}^{-} / \mathrm{I}_{3}{ }^{-}$, redox couple is $0.35 \mathrm{~V}$ (vs. the normal hydrogen electrode) [69].The reduction and thus coloration of viologen is then possible through the oxidation of $\mathrm{I}^{-}$to $2 \mathrm{I}_{2}{ }^{- \text {. }}$ (eq. 3) which occurs at $0.8 \mathrm{~V}$ [70] vs. NHE. It corresponds to $0.7 \mathrm{~V}$ bias needed to transfer the electrons from the the $\mathrm{I}^{-} / \mathrm{I}_{2}{ }^{-\cdot}$ level to the FTO and then to the external circuit at the $\mathrm{TiO}_{2}$, which further injects the electrons into viologen, which level is situated at $0.35 \mathrm{eV}$ vs. NHE [71,72].

The experimental reduction potential $(-1.15 \mathrm{~V}$ vs FTO and thus $-1.05 \mathrm{~V}$ vs. NHE) is slightly higher than the theoretical value due to electrode polarization or parasitic reactions related overpotential. The bleaching practically needs no bias since the electron will be readily transferred from FTO or viologen to the $\mathrm{I}_{3}{ }^{-} / \mathrm{I}^{-}$level for regenerating the $\mathrm{I}^{-}$(eq. 4 ) and then to viologen. Once the bias is removed, the system will tend to regain the equilibrium, the transfer of electrons from viologen back to the redox couple will prevail, thus explaining the whitening of the device in open circuit. The transfer of electrons from the viologen back to the electrolyte is a parasitic reaction which can slow down the blue coloration and contribute to parasitic current. 


$$
\begin{aligned}
& \mathrm{I}_{3}{ }^{-}+2 \mathrm{e}^{-} \rightarrow 3 \mathrm{I}^{-}(2) \\
& 2 \mathrm{I}^{-}-\mathrm{e}^{-} \rightarrow 2 \mathrm{I}_{2}{ }^{-\cdot}(3) \\
& \mathrm{I}_{3}{ }^{-}+2 \mathrm{e}^{-} \rightarrow 3 \mathrm{I}^{-}
\end{aligned}
$$

The open-circuit memory effect was examined using an all-or-nothing relay coupled with reflectance measurements. Figure 5 shows the two first cycles of the resulting optical response between blue state at $-1.5 \mathrm{~V}$ and white state in open circuit. After a plateau in coloration state ( $\mathrm{R} \sim 18 \%$ ), the system returns immediately to the open circuit voltage OCV in less than 15 seconds.

One of the most important requirements for all EC devices is a lifetime as long as possible. Figure 6 illustrates the result of a lifetime study between the white and blue colored states of the ECD by cyclic chronoamperometry for 20000 cycles. In Fig. 6a four individual cycles, namely the $1^{\text {st }}, 1000^{\text {th }}, 10000^{\text {th }}$ and $20000^{\text {th }}$ are compared while Fig. $6 \mathrm{~b}$ shows the corresponding evolution of the electrochemical capacity. At first glance, the highest current density value appears to decrease very slightly upon cycling and the cycle becomes smaller in intensity taking into account the progressive evolution of the current density in both cathodic and anodic parts. The repetitive cycling shows good reversibility and high stability in terms of capacity up to 20000 cycles. The decrease in capacity of about $20 \%$ in between the first and the $4000^{\text {th }}$ cycle, may be ascribed to the evaporation of remaining water in the electrolyte or other non-identified phenomena, while no significant degradation is further observed. The electrochemical capacity of $0.81 \mathrm{mC} . \mathrm{cm}^{-2}$ remains stable upon cycling.

Figure $7(a, b)$ show the corresponding in-situ reflectance responses of cyclic chronoamperometry (Fig. 6a) and voltammetry for 20000 cycles, respectively. The reflectance cycles of $1^{\text {st }}$ and $1000^{\text {th }}$ cycles appear quite identical while from the $10000^{\text {th }}$ cycles, both reflectance modulation and the time in oxidation show some degradation. A loss of about $26 \%$ of electrochromic performances in terms of $\Delta \mathrm{R}$ was deduced while the time to whiten increases up to 10 seconds. A similar behavior was observed also for in-situ reflectance of voltammetry measurements illustrated by an increase in the width of the cycle and decrease in $\Delta \mathrm{R}$ modulation (Fig. 6b). Indeed, the $1000^{\text {th }}$ cycle shows the smallest hysteresis with the highest $\Delta \mathrm{R}$ value ( $19 \%)$. The $20000^{\text {th }}$ shows the largest width and hysteresis linked to higher coloration (reduction) time $(\mathrm{t} \sim 10 \mathrm{~s})$ while the de-coloration (oxidation) time $(\mathrm{t} \sim 5 \mathrm{~s})$ remains almost stable upon cycling. 
Table 2 gathers the $\mathrm{L}^{*}, \mathrm{a}^{*}, \mathrm{~b}^{*}$ parameters and $\Delta \mathrm{E}^{*}$, as well as the $\Delta \mathrm{R}$ at blue $(-1.5 \mathrm{~V})$ and white $(0 \mathrm{~V})$ states as a function of cycle number. Upon cycling, the luminance $\mathrm{L}^{*}$ at $0 \mathrm{~V}$ slightly decreases, the $\mathrm{b}^{*}$ parameter goes negative during coloration switching from 21 at $0 \mathrm{~V}$ to -31 at $-1.5 \mathrm{~V}$, as a confirmation of bluish coloration formation. The optical contrast $\left(\Delta \mathrm{E}^{*}\right)$ reflects high electrochromic performances of this EC device with losses around $1 / 10$ in $\Delta \mathrm{E}^{*}$ and $1 / 4$ in $\Delta \mathrm{R}$ between the first and $20000^{\text {th }}$ cycle.

\section{Conclusion}

A simplified electrochromic device based on viologen anchored - nanostructured $\mathrm{TiO}_{2}$ as cathodic electrochromic material and $\mathrm{I}^{-} / \mathrm{I}_{3}{ }^{-}$based gelatin electrolyte as counter electrode has been developed. The novel electrolyte formulation consists of a gelatin based electrolyte of high ionic conductivity, high transmittance and physico-electrochemical stability which represents a cheap and eco-friendly alternative to polymer membrane electrolytes for ECD manufacturing. High electrochromic performances with high electrochemical stability (over 20000 cycles) were successfully demonstrated.

Due to the non-toxic electrolyte as well as simple architecture, the developed electrochromic device can be a promising candidate for current commercialized displays.

\section{Acknowledgements}

The authors wish to thank Mathias Da Rocha for helpful discussion. 


\section{References}

[1] C.G. Granqvist, Preface, Handbook of Inorganic Electrochromic Materials, Elsevier Science B.V., Amsterdam, 1995, p. vii-viii.

[2] G.A. Niklasson, C.G. Granqvist, Electrochromics for smart windows: thin films of tungsten oxide and nickel oxide, and devices based on these, J Mater. Chem., 17 (2007) 127-156.

[3] G.B. Smith, C.G. Granqvist, Green nanotechnology: solutions for sustainability and energy in the built environment, Taylor \& Francis Inc, Bosa Roca, USA, 2010, p. 472.

[4] C.G. Granqvist, Electrochromics for Energy-Efficient Buildings: Nanofeatures, Thin Films, and Devices, Nanotechnology for the Energy Challenge, Wiley-VCH Verlag GmbH \& Co. KGaA2013, p. 593-617.

[5] F. Pacheco-Torgal, M.V. Diamanti, A. Nazari, C. Goran-Granqvist, Nanotechnology in Eco-Efficient Construction, Woodhead Publishing, 2013.

[6] A. Llordes, G. Garcia, J. Gazquez, D.J. Milliron, Tunable near-infrared and visible-light transmittance in nanocrystal-in-glass composites, Nature, 500 (2013) 323-326.

[7] A. Danine, L. Cojocaru, C. Faure, C. Olivier, T. Toupance, G. Campet, A. Rougier, Room Temperature UV treated $\mathrm{WO}_{3}$ thin films for electrochromic devices on paper substrate, Electrochim. Acta, 129 (2014) 113-119.

[8] P.M. Beaujuge, J.R. Reynolds, Color Control in $\pi$-Conjugated Organic Polymers for Use in Electrochromic Devices, Chem. Rev., 110 (2010) 268-320.

[9] J. Palenzuela, A. Viñuales, I. Odriozola, G. Cabañero, H.J. Grande, V. Ruiz, Flexible Viologen Electrochromic Devices with Low Operational Voltages Using Reduced Graphene Oxide Electrodes, ACS Appl. Mater. Interfaces, 6 (2014) 14562-14567.

[10] http://sageglass.com/fr/

[11] C.M. Lampert, C.G. Granqvist, Large-area chromogenics: Materials and devices for transmittance control. Volume IS 4, SPIE-The International Society for Optical Engineering, Bellingham, WA (United States), 1990.

[12] http://www.washington.edu/news/2007/03/27/smart-sunglasses-and-goggles-let-usersadjust-shade-and-color/.

[13] http://www.saint-gobain-sekurit.com/fr/.

[14] P. Andersson, D. Nilsson, M. Berggren, P.O. Svensson, N.D. Robinsson, Electrochemical device, Google Patents, 2011.

[15] G. Copeland, A. Briancon, M. Moeller, N. Leyland, C. Giacoponello, M. Cassidy, C. Grave, D. Corr, D. Bevk, M. Ryan, Advanced electrode structures and electrochromic devices, Google Patents, 2012.

[16] S.K. Deb, Optical and photoelectric properties and colour centres in thin films of tungsten oxide, Philos. Mag., 27 (1973) 801-822.

[17] Dimitra Vernardou, Konstantinos Psifis, Dimitris Louloudakis, George Papadimitropoulos, Dimitris Davazoglou, Nikolaos Katsarakis, and Emmanouil Koudoumas, Low pressure CVD of Electrochromic $\mathrm{WO}_{3}$ at $400{ }^{\circ} \mathrm{C}$, Journal of The Electrochemical Society 162 (2015) H579-H582

[18] Konstantinos Psifis, Dimitris Louloudakis, Dimitra Vernadou, Emmanuel Spanakis, George Papadimitropoulos Dimitris Davazoglou, Nikolaos Katsarakis, Emmanuel Koudoumas, Effect of $\mathrm{O}_{2}$ flow rate on the electrochromic response of $\mathrm{WO}_{3}$ grown by LPCVD, Physica status solidi (c) 12 (2015) 1011-1015

[19] A. Azens, E. Avendaño, J. Backholm, L. Berggren, G. Gustavsson, R. Karmhag, G.A. Niklasson, A. Roos, C.G. Granqvist, Flexible foils with electrochromic coatings: science, technology and applications, Mater. Sci. Eng. B, 119 (2005) 214-223.

[20] M. Buyan, P.A. Brühwiler, A. Azens, G. Gustavsson, R. Karmhag, C.G. Granqvist, Facial warming and tinted helmet visors, Int. J. Ind. Ergonom., 36 (2006) 11-16. 
[21] Y. Dai, W. Li, X. Qu, J. Liu, S. Yan, M. Ouyang, X. Lv, C. Zhang, Electrochemistry, Electrochromic and Color Memory Properties of Polymer/Copolymer Based on Novel Dithienylpyrrole Structure, Electrochim. Acta, 229 (2017) 271-280.

[22] C. Chotsuwan, U. Asawapirom, Y. Shimoi, H. Akiyama, A. Ngamaroonchote, T. Jiemsakul, K. Jiramitmongkon, Investigation of the electrochromic properties of tri-block polyaniline-polythiophene-polyaniline under visible light, Synth. Met., 226 (2017) 80-88.

[23] X. Yang, C. Liu, J. Guo, L. Wang, G. Nie, A Free-standing electrochromic material of poly(5,7-bis(2-(3,4-ethylenedioxy)thienyl)-indole) and its application in electrochromic device, J. Polym. Sci. Pol. Chem. Part A, 55(14) (2017) 2356-2364.

[24] S. Pai, M. Moos, M.H. Schreck, C. Lambert, D.G. Kurth, Green-to-Red Electrochromic $\mathrm{Fe}(\mathrm{II})$ Metallo-Supramolecular Polyelectrolytes Self-Assembled from Fluorescent 2,6-Bis(2pyridyl)pyrimidine Bithiophene, Inorg. Chem., 56 (2017) 1418-1432.

[25] P.Y. Chang, C.H. Yang, Photopolymerization of electroactive film applied to full polymer electrochromic device, Express Polym. Lett., 11 (2017) 176-186.

[26] P.M.S. Monk, R.J. Mortimer, D.R. Rosseinsky, Electroactive Conducting Polymers, Electrochromism, Wiley-VCH Verlag GmbH, 2007, p. 143-171.

[27] J. Heinze, Electronically conducting polymers, in: E. Steckhan (Ed.) Electrochemistry IV, Springer Berlin Heidelberg, Berlin, Heidelberg, 1990, p. 1-47.

[28] G.P. Evans, The Electrochemistry of Conducting Polymers, Advances in Electrochemical Science and Engineering, Wiley-VCH Verlag GmbH, 2008, p. 1-74.

[29] M. Mastragostino, Electrochromic devices, in: B. Scrosati (Ed.) Applications of Electroactive Polymers, Springer Netherlands, Dordrecht, 1993, p. 223-249.

[30] J. Roncali, Conjugated poly(thiophenes): synthesis, functionalization, and applications, Chem. Rev., 92 (1992) 711-738.

[31] S.J. Higgins, Conjugated polymers incorporating pendant functional groups-synthesis and characterisation, Chem. Soc. Rev., 26 (1997) 247-257.

[32] C.L. Bird, A.T. Kuhn, Electrochemistry of the viologens, Chem. Soc. Rev., 10 (1981) 4982.

[33] A.J. Bard, A. Ledwith, H.J. Shine, Formation, Properties and Reactions of Cation Radicals in Solution, in: V. Gold, D. Bethell (Eds.) Advances in Physical Organic Chemistry, Academic Press, 1976, pp. 155-278.

[34] W. Sliwa, B. Bachowska, N. Zelichowicz, Chemistry of viologens, Heterocycles, 32 (1991) 2241-2273.

[35] H.-C. Lu, S.-Y. Kao, T.-H. Chang, C.-W. Kung, K.-C. Ho, An electrochromic device based on Prussian blue, self-immobilized vinyl benzyl viologen, and ferrocene, Sol. Energ. Mat. Sol. Cells, 147 (2016) 75-84.

[36] P. Bonhôte, E. Gogniat, F. Campus, L. Walder, M. Grätzel, Nanocrystalline electrochromic displays, Displays, 20 (1999) 137-144.

[37] http://www.wired.com/gadgetlab/2010/04/ntera-printable-display/.

[38] D. Corr, U. Bach, D. Fay, M. Kinsella, C. McAtamney, F. O'Reilly, S.N. Rao, N. Stobie, Coloured electrochromic "paper-quality" displays based on modified mesoporous electrodes, Solid State Ionics, 165 (2003) 315-321.

[39] Y. Rong, S. Kim, F. Su, D. Myers, M. Taya, New effective process to fabricate fast switching and high contrast electrochromic device based on viologen and Prussian blue/antimony tin oxide nano-composites with dark colored state, Electrochim. Acta, 56 (2011) 6230-6236.

[40] M.-S. Fan, S.-Y. Kao, T.-H. Chang, R. Vittal, K.-C. Ho, A high contrast solid-state electrochromic device based on nano-structural Prussian blue and poly(butyl viologen) thin films, Sol. Energ. Mat. Sol. Cells, 145 (2016) 35-41. 
[41] Y. Alesanco, J. Palenzuela, R. Tena-Zaera, G. Cabañero, H. Grande, B. Herbig, A. Schmitt, M. Schott, U. Posset, A. Guerfi, M. Dontigny, K. Zaghib, A. Viñuales, Plastic electrochromic devices based on viologen-modified $\mathrm{TiO}_{2}$ films prepared at low temperature, Sol. Energ. Mat. Sol. Cells, 157 (2016) 624-635.

[42] T.-H. Kuo, C.-Y. Hsu, K.-M. Lee, K.-C. Ho, All-solid-state electrochromic device based on poly(butyl viologen), Prussian blue, and succinonitrile, Sol. Energ. Mat. Sol. Cells, 93 (2009) 1755-1760.

[43] M. Li, Y. Wei, J. Zheng, D. Zhu, C. Xu, Highly contrasted and stable electrochromic device based on well-matched viologen and triphenylamine, Org. Electron., 15 (2014) 428-434.

[44] C.S. Ah, J. Song, S.M. Cho, T.-Y. Kim, H. Ryu, S. Cheon, J.Y. Kim, C.-S. Hwang, Y.-H. Kim, Optical and Electrical Properties of Electrochromic Devices Depending on Electrolyte Concentrations and Cell Gaps, Bull. Korean Chem. Soc., 37 (2016) 1812-1819.

[45] H.J. Kim, J.K. Seo, Y.J. Kim, H.K. Jeong, G.I. Lim, Y.S. Choi, W.I. Lee, Formation of ultrafast-switching viologen-anchored $\mathrm{TiO} 2$ electrochromic device by introducing Sb-doped SnO2 nanoparticles, Sol. Energ. Mat. Sol. Cells, 93 (2009) 2108-2112.

[46] L.-p. Gao, G.-j. Ding, Y.-c. Wang, Y.-1. Yang, Preparation of UV curing crosslinked polyviologen film and its photochromic and electrochromic performances, Appl. Surf. Sci., 258 (2011) 1184-1191.

[47] G. Eymin-Petot-Tourtollet, M. Braha-Lonchant, M. Verelst, G. Campet, A. Rougier, T.P. Vuong, P. Benech, P. Xavier, and J.M. Duchamp, «Dispositif électronique d'authentification.», Patent FR 1155286 (2011).

[48] A. Danine, C. Faure, G. Campet, A. Rougier, Electrochromic Device Comprising Three or Four Layers, Patent WO2014/135804A1 / US2016/0011482A1.

[49] http://cordis.europa.eu/project/rcn/105691_en.html.

[50] C.-F. Lin, C.-Y. Hsu, H.-C. Lo, C.-L. Lin, L.-C. Chen, K.-C. Ho, A complementary electrochromic system based on a Prussian blue thin film and a heptyl viologen solution, Sol. Energ. Mat. Sol. Cells, 95 (2011) 3074-3080.

[51] B. Scrosati, Laminated electrochromic displays and windows, in: B. Scrosati (Ed.) Applications of Electroactive Polymers, Springer Netherlands, Dordrecht, 1993, p. 250-282.

[52] P. Hagenmuller, W. Van Gool, 32 - Application Prospects of Solid Electrolytes, Solid Electrolytes, Academic Press, 1978, p. 535-543.

[53] D. Deroo, Second International Symposium on Polymer Electrolytes in: B. Scrosati (Ed.) Second International Symposium on Polymer Electrolytes, Elsevier Applied Science, London; New York, 1990, p. 433.

[54] P. Wasserscheid, T. Welton, Outlook, Ionic Liquids in Synthesis, Wiley-VCH Verlag GmbH \& Co. KGaA2008, p. 689-704.

[55] C.E. Tambelli, J.P. Donoso, A.M. Regiani, A. Pawlicka, A. Gandini, J.F. LeNest, Nuclear magnetic resonance and conductivity study of $\mathrm{HEC} /$ polyether-based polymer electrolytes, Electrochim. Acta, 46 (2001) 1665-1672.

[56] A. Pawlicka, D.C. Dragunski, C.O. Avellaneda, Electrochromic Devices with Starch Based Solid Polymeric Electrolytes, in: A. Graja, B.R. Bułka, F. Kajzar (Eds.) Molecular Low Dimensional and Nanostructured Materials for Advanced Applications, Springer Netherlands, Dordrecht, 2002, p. 255-258.

[57] Z. Osman, Z.A. Ibrahim, A.K. Arof, Conductivity enhancement due to ion dissociation in plasticized chitosan based polymer electrolytes, Carbohydr. Polym., 44 (2001) 167-173.

[58] B. Orel, A. Šurca Vuk, R. Ješe, P. Lianos, E. Stathatos, P. Judeinstein, P. Colomban, Development of sol-gel redox I3-/I- electrolytes and their application in hybrid electrochromic devices, Solid State Ionics, 165 (2003) 235-246.

[59] A. Georg, A. Georg, Electrochromic device with a redox electrolyte, Sol. Energ. Mat. Sol. Cells, 93 (2009) 1329-1337. 
[60] M. Čolović, A. Šurca Vuk, M. Hajzeri, B. Orel, Structural studies of alkoxysilylfunctionalised ionic liquid and its application in a hybrid electrochromic device, Mater. Res. Bull., 47 (2012) 3160-3169.

[61] M. Čolović, I. Jerman, M. Gaberšček, B. Orel, POSS based ionic liquid as an electrolyte for hybrid electrochromic devices, Sol. Energ. Mat. Sol. Cells, 95 (2011) 3472-3481.

[62] S. Bogati, A. Georg, C. Jerg, W. Graf, Tetramethylthiourea (TMTU) as an alternative redox mediator for electrochromic devices, Sol. Energ. Mat. Sol. Cells, 157 (2016) 454-461.

[63] H.-C. Lu, S.-Y. Kao, H.-F. Yu, T.-H. Chang, C.-W. Kung, K.-C. Ho, Achieving LowEnergy Driven Viologens-Based Electrochromic Devices Utilizing Polymeric Ionic Liquids, ACS Appl. Mater. Interfaces, 8 (2016) 30351-30361.

[64] http://fr.solvionic.com/.

[65] R. Baskaran, S. Selvasekarapandian, N. Kuwata, J. Kawamura, T. Hattori, ac impedance, DSC and FT-IR investigations on (x)PVAc- $(1-\mathrm{x}) \mathrm{PVdF}$ blends with LiClO4, Mater. Chem. Phys., 98 (2006) 55-61.

[66] A. Hagfeldt, N. Vlachopoulos, M. Gratzel, Fast Electrochromic switching with nanocrystalline oxide semiconductor films, J. Electrochem. Soc., 141 (1994) L82-L84.

[67] F. Campus, P. Bonhôte, M. Grätzel, S. Heinen, L. Walder, Electrochromic devices based on surface-modified nanocrystalline TiO2 thin-film electrodes, Sol. Energ. Mat. Sol. Cells, 56 (1999) 281-297.

[68] G. Alemu, J. Li, J. Cui, X. Xu, B. Zhang, K. Cao, Y. Shen, Y. Cheng, M. Wang, Investigation on regeneration kinetics at perovskite/oxide interface with scanning electrochemical microscopy, J. Mater. Chem. A, 3 (2015) 9216-9222.

[69] G. Boschloo, A. Hagfeldt, Characteristics of the Iodide/Triiodide Redox Mediator in DyeSensitized Solar Cells, Acc. Chem. Res., 42 (2009) 1819-1826.

[70] K.C.D. Robson, P.G. Bomben, C.P. Berlinguette, Cycloruthenated sensitizers: improving the dye-sensitized solar cell with classical inorganic chemistry principles, Dalton Trans., 41 (2012) 7814-7829.

[71] J.-B. Jiang, P. Huo, P. Wang, Y.-Y. Wu, G.-Q. Bian, Q.-Y. Zhu, J. Dai, Synthesis and photocurrent responsive properties of CdS/Se clusters integrated with methylviologen, J. Mater. Chem. C, 2 (2014) 2528-2533.

[72] R. Sydam, A. Ghosh, M. Deepa, Enhanced electrochromic write-erase efficiency of a device with a novel viologen: 1,1'-bis(2-(1H-indol-3-yl)ethyl)-4,4'-bipyridinium diperchlorate, Org. Electron., 17 (2015) 33-43. 


\section{Figure captions}

Figure 1 : Impedance spectra of the 0.3 eq. LiI/BMII. 15 wt. \% gelatin electrolyte. A zoom in the highfrequency region is shown in the inset.

Figure 2: First ten cyclic voltammograms of $\mathrm{TiO}_{2}$-viologen film $\left(S \approx 1 \mathrm{~cm}^{2}\right)$ cycled in $\mathrm{TiO}_{2}-$ viologen/0.3 eq. LiI-BMII/Pt vs. $\mathrm{Hg} / \mathrm{HgO}$ cells in between $-0.5 \mathrm{~V}$ to $0 \mathrm{~V}$ with a scan rate of $10 \mathrm{mV} / \mathrm{s}$. Inset: representation of the coloration and open circuit bleaching mechanism of the glass/FTO/ $\mathrm{TiO}_{2}-$ viologen/0.3 eq. LiI-BMITFSI 15 wt. \% gelatin/ FTO/glass device.

Figure 3: (a) In-situ cyclic voltammogram $\left(2^{\text {nd }}\right.$ cycle $) /$ reflectance at $550 \mathrm{~nm}$ of glass/FTO/TiO $2^{-}$ viologen/0.3 eq. LiI-BMITFSI 15 wt. \% gelatin/FTO/glass device, started on reduction in between -1.5 $\mathrm{V}$ to $0 \mathrm{~V}$ with a scan rate of $10 \mathrm{mV} / \mathrm{s}$. Inset : reversible color change from bluish $(-1.5 \mathrm{~V})$ to whitish $(0$ V) state. (b) The corresponding in-situ chronoamperogramms/reflectance at $550 \mathrm{~nm}$ at $-1.5 \mathrm{~V}$ for $20 \mathrm{~s}$ and $0 \mathrm{~V}$ for $20 \mathrm{~s}$.

Figure 4: Electrochromic device consisting of $\mathrm{TiO}_{2}$-viologen film on glass/FTO substrate as cathodic electrochromic material and $\mathrm{I}^{-} / \mathrm{I}_{3}^{-}$redox couple electrolyte with 0.3 eq. LiI/BMI in 15 wt. \% gelatin on glass/FTO.

Figure 5 : Memory effect evaluation by studying the variation of reflectance of the glass/FTO/ $\mathrm{TiO}_{2}-$ viologen/0.3 eq. LiI/BMITFSI. 15 wt. \% gelatin/FTO/glass device, by using an all-or-nothing relay, i.e. $-1.5 \mathrm{~V}$ for $20 \mathrm{~s}$ and open circuit for $20 \mathrm{~s}$, respectively (the first two cycles are shown).

Figure 6: (a) Evolution of in-situ reflectance up to 20,000 cycles of glass/FTO/TiO ${ }_{2}$-viologens/0.3 eq. LiI/BMITFSI. 15 wt. \% gelatin/FTO/glass device resulting from in-situ cyclic chronoamperometry in between $-1.5 \mathrm{~V}$ for $20 \mathrm{~s}$ and $0 \mathrm{~V}$ for $20 \mathrm{~s}$. (b) Evolution of in-situ reflectance up to 20,000 cycles resulting from in-situ cyclic voltammetry in between $-1.5 \mathrm{~V}$ and $0 \mathrm{~V}$ with a scan rate of $10 \mathrm{mV} / \mathrm{s}$.

Figure 7 : (a) Evolution of the cyclic chronoamperograms for the glass/FTO/TiO ${ }_{2}$-viologen $/ 0.3$ eq. LiI/BMITFSI. 15 wt. \% gelatin/FTO/glass device cycled up to 20,000 cycles at $-1.5 \mathrm{~V}$ for $20 \mathrm{~s}$ and $0 \mathrm{~V}$ for $20 \mathrm{~s}$. (b) Corresponding variation of the anodic capacity upon cycling. 


\section{Table Captions :}

Table 1: Ionic conductivity of the 0.3 eq. LiI/BMII. 15 wt. \% gelatin electrolyte (analysis performed for three parallel samples) as a function of resistances deduced from impedance spectra.

Table 2: Reflectance modulation $\Delta \mathrm{R}$ and optical contrast $\Delta \mathrm{E}^{*}\left(\mathrm{CIE}^{*} \mathrm{~L}^{*} \mathrm{a}^{*} \mathrm{~b}^{*}\right)$ of glass/FTO/TiO $2^{-}$ viologen/0.3 eq. LiI/BMITFSI. 15 wt. \% gelatin/FTO/glass device between the bluish $(-1.5 \mathrm{~V})$ and whitish (0 V) state up to 20,000 cycles. 
Table 1

\begin{tabular}{ccccc}
\hline Sample & $\mathbf{d}(\mathbf{c m})$ & $\mathbf{R}(\boldsymbol{\Omega})$ & $\boldsymbol{\sigma}(\mathbf{m S} / \mathbf{c m})$ & $\boldsymbol{\sigma}_{\text {av. }}(\mathbf{m S} / \mathbf{c m})$ \\
\hline $\mathbf{1}$ & 0.182 & 17.82 & 3.2 \\
$\mathbf{2}$ & 0.182 & 14.06 & 4.1 \\
$\mathbf{3}$ & 0.186 & 16.69 & 3.5
\end{tabular}


Table 2

\begin{tabular}{ccccccccc}
\hline Cycle & & \multicolumn{1}{c}{$\mathbf{L}^{*}$} & \multicolumn{2}{c}{$\mathbf{a}^{*}$} & $\mathbf{b}^{*}$ & $\mathbf{\Delta} \mathbf{E}^{*}$ & $\boldsymbol{\Delta} \mathbf{R} \%$ \\
\hline & $\mathbf{- 1 . 5} \mathbf{V}$ & $\mathbf{0 ~ V}$ & $\mathbf{- 1 . 5} \mathbf{V}$ & $\mathbf{0 V}$ & $\mathbf{- 1 . 5} \mathbf{V}$ & $\mathbf{0 ~ V}$ & & \\
\hline $\mathbf{1}$ & 40.69 & 59.49 & -4.78 & -10.00 & -32.60 & 22.92 & 58.84 & 19,00 \\
$\mathbf{1 0 0 0}$ & 40.89 & 58.52 & -4.52 & -9.88 & -31.71 & 21.73 & 56.52 & 18.14 \\
$\mathbf{1 0 ~ 0 0 0}$ & 40.74 & 58.15 & -4.14 & -9.22 & -31.47 & 20.81 & 55.33 & 17.13 \\
$\mathbf{2 0 ~ 0 0 0}$ & 40.58 & 57.87 & -3.76 & -9.01 & -31.23 & 19.12 & 53.49 & 14.07 \\
\hline
\end{tabular}


Figure 1

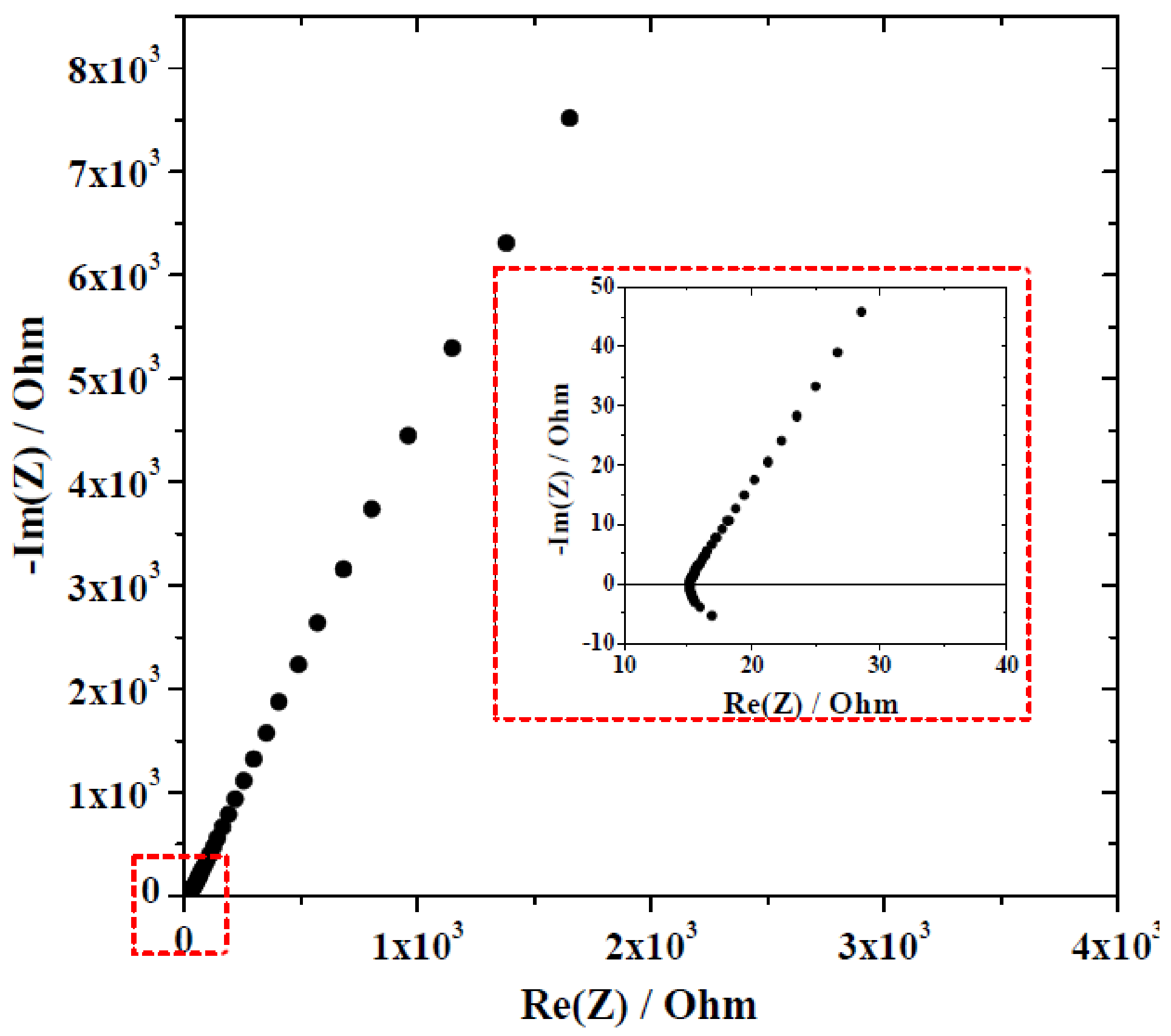


Figure 2

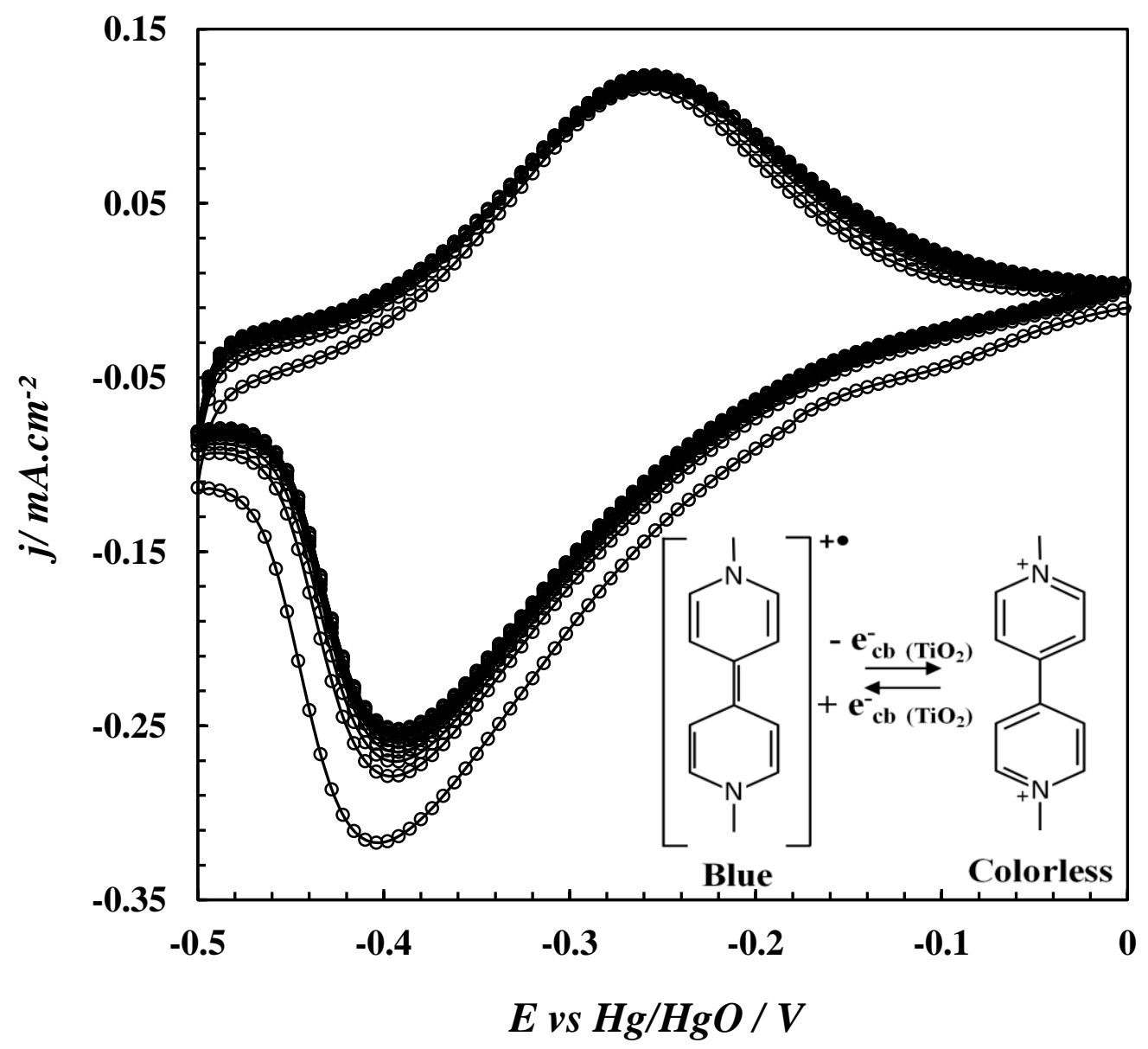


Figure 3
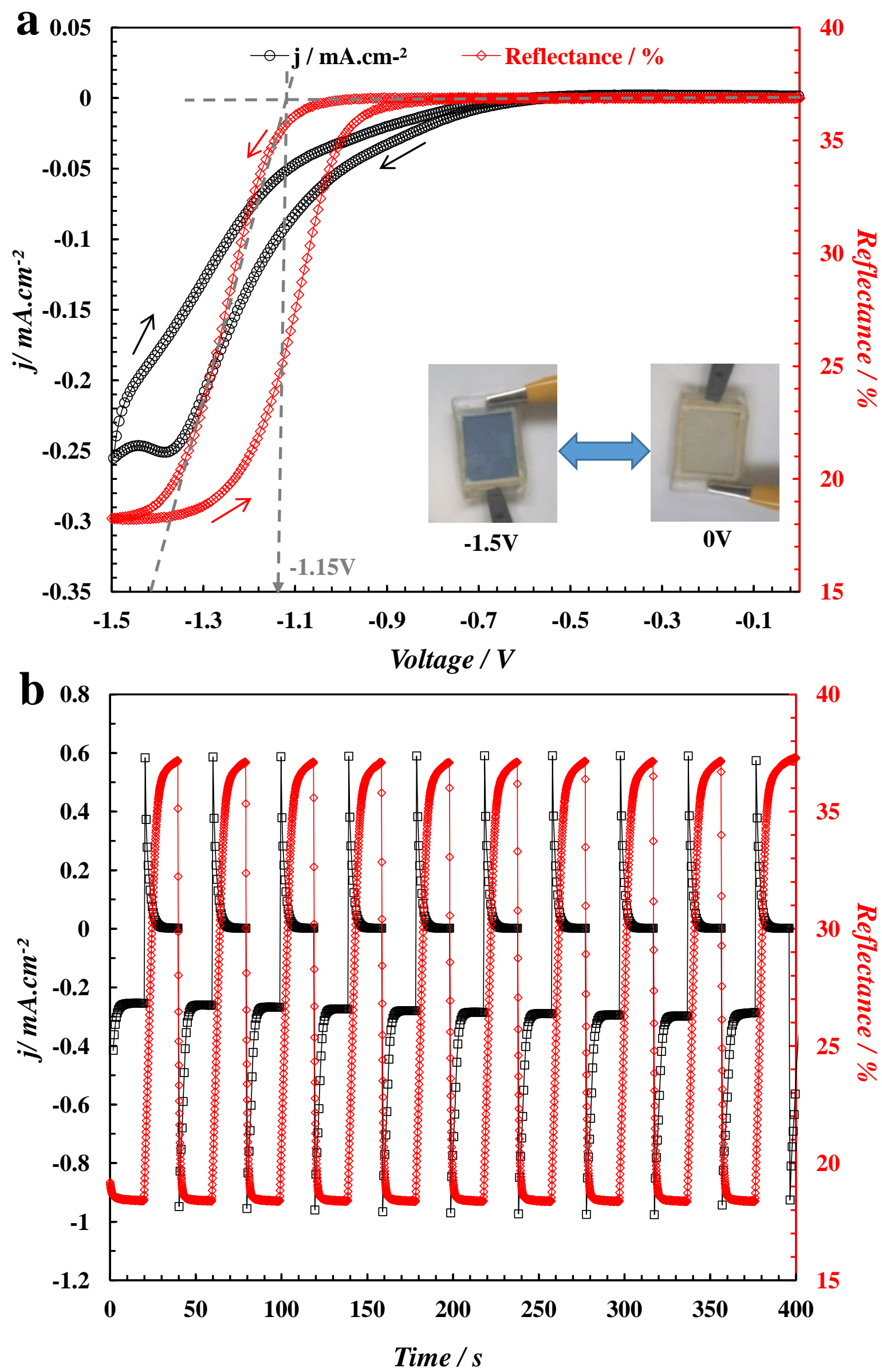
Figure 4

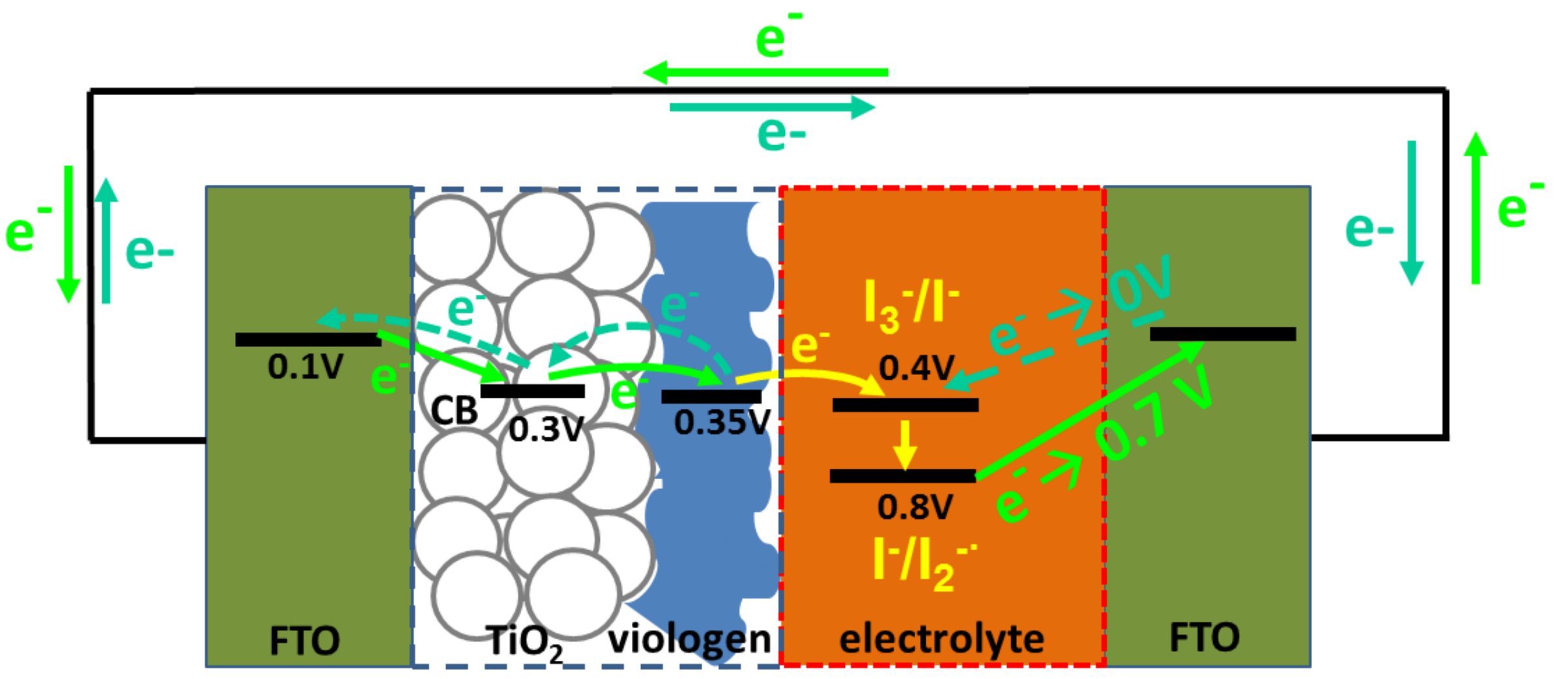


Figure 5

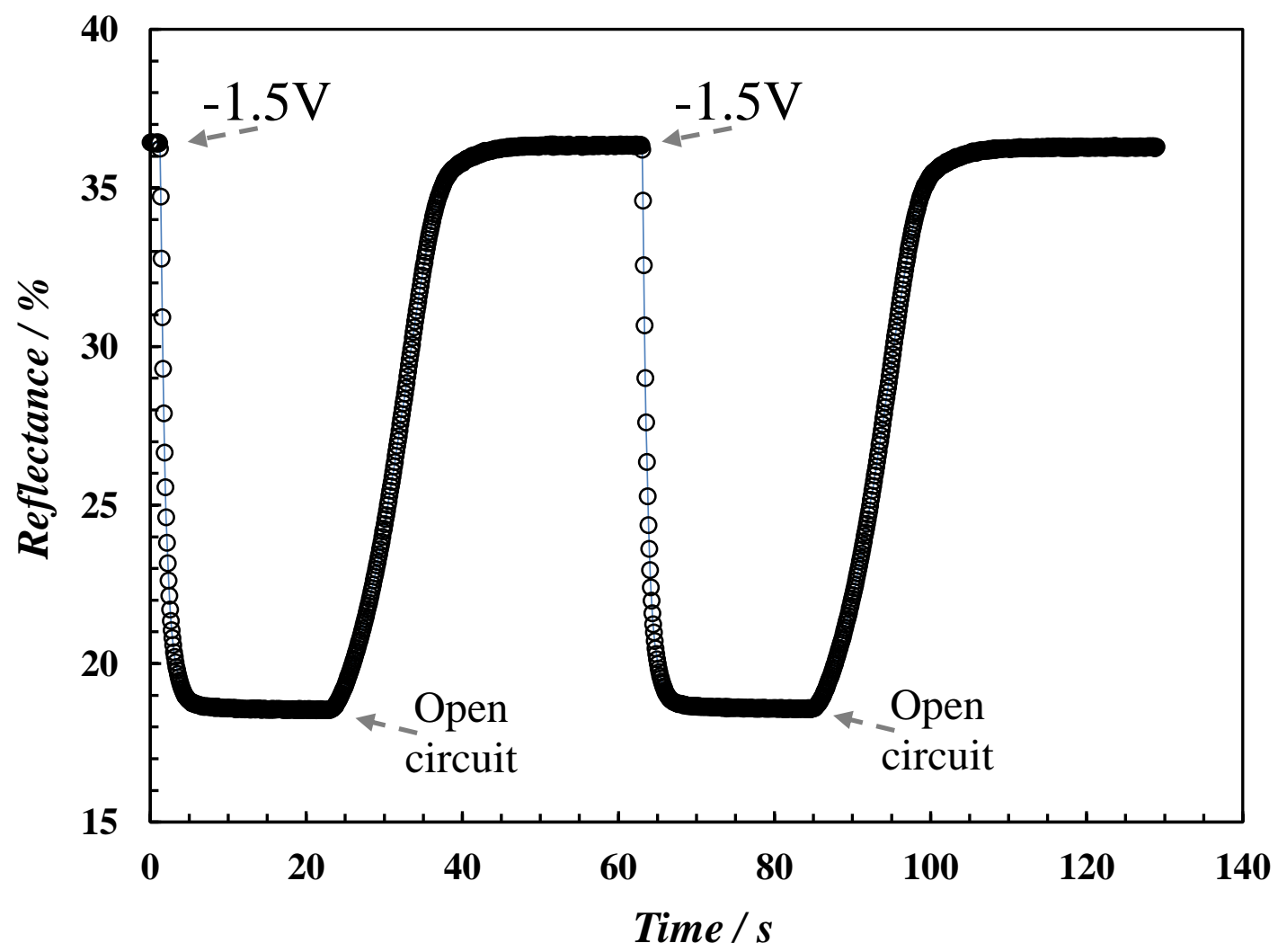


Figure 6
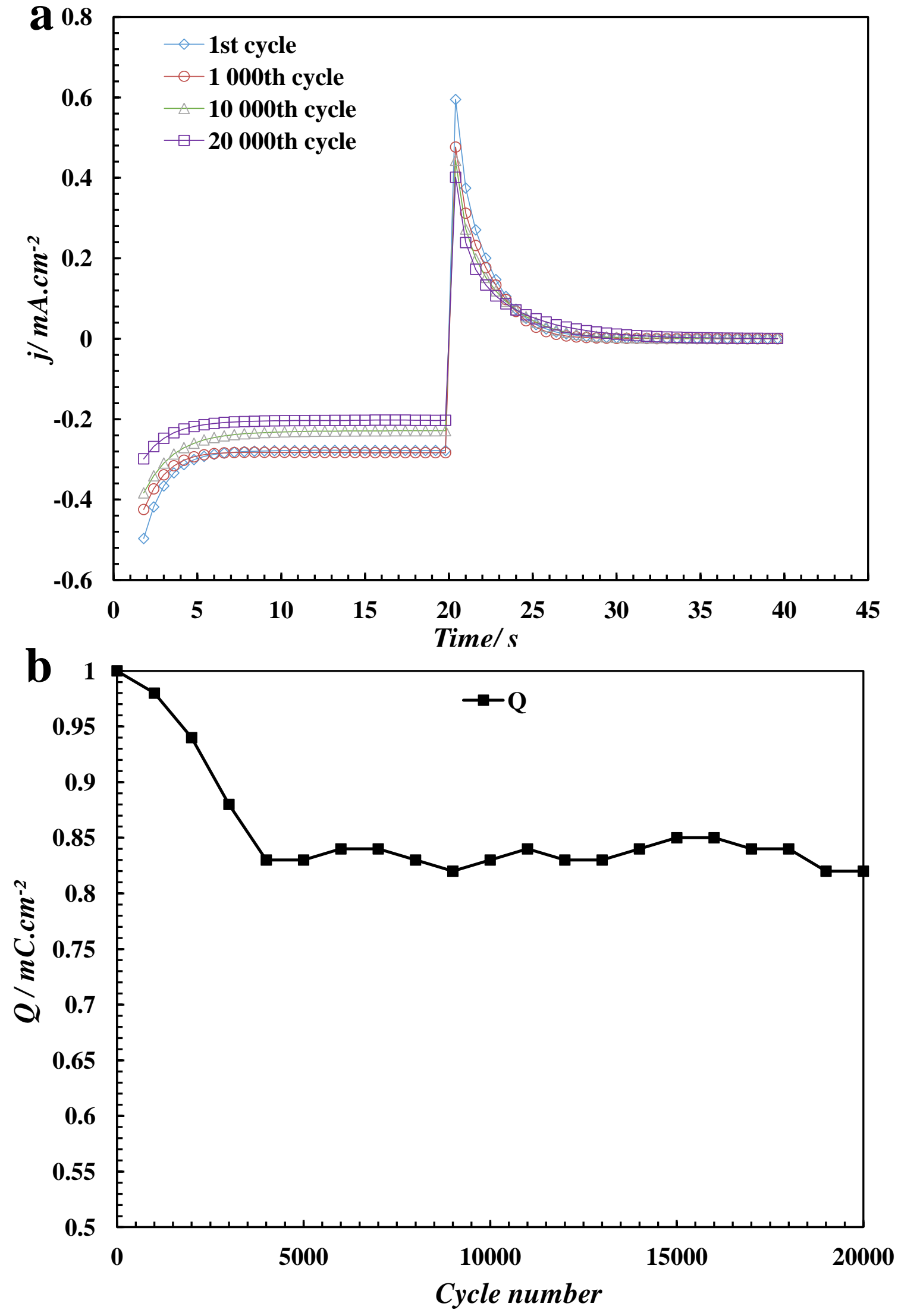


\section{Figure 7}
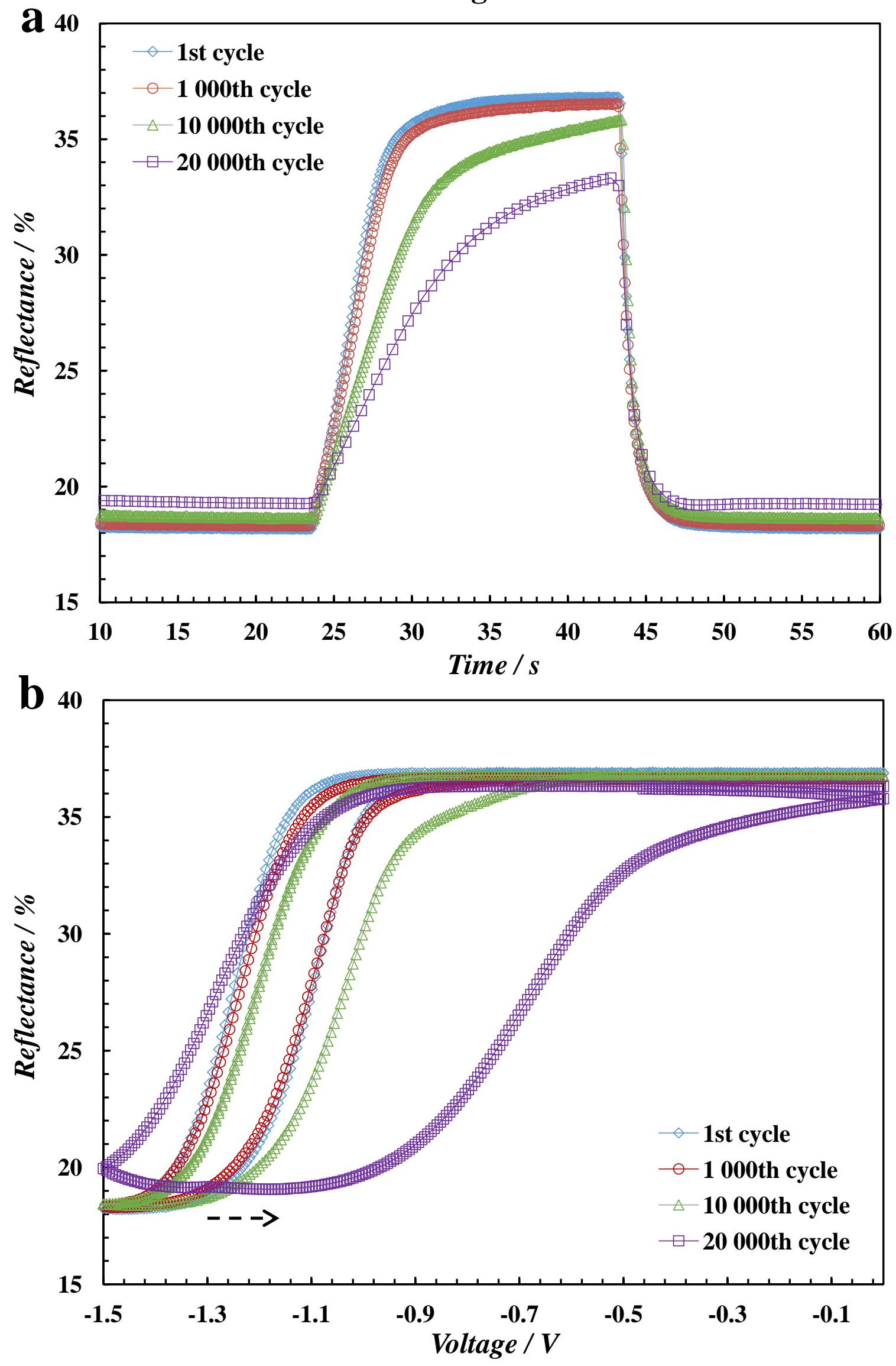